
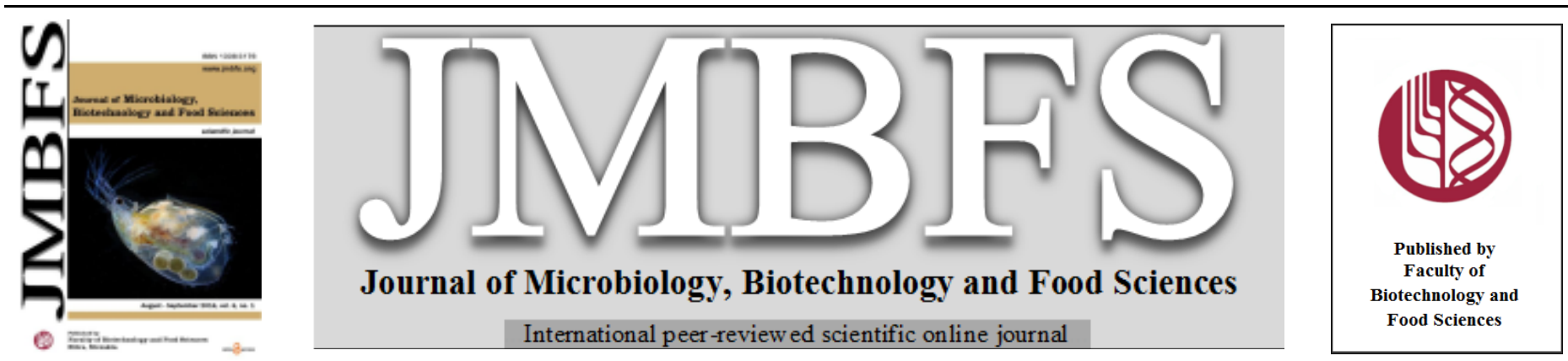

\title{
INACTIVATION OF SHIGA-TOXIN PRODUCING Escherichia coli (STEC) O157:H7 IN MILK BY COMBINED TREATMENT WITH HIGH HYDROSTATIC PRESSURE AND AQUEOUS POMEGRANATE EXTRACT
}

\section{Robert Alvin Bernedo-Navarro* ${ }^{1}$, Ricardo Durães-Carvalho ${ }^{1}$, Ancelmo Rabelo de Souza ${ }^{3}$, Mayara Mayele Miyachiro ${ }^{2}$, Carlos Francisco Sampaio Bonafe ${ }^{3}$ and Tomomasa Yano ${ }^{l}$}

\author{
Address(es): \\ ${ }^{1}$ Department of Genetics, Evolution and Bioagents, Institute of Biology, State University of Campinas (UNICAMP), Campinas, SP, Brazil. \\ ${ }^{2}$ Brazilian National Laboratory for Biosciences (LNBio), Campinas, SP, Brazil. \\ ${ }^{3}$ Department of Biochemistry, Institute of Biology, University of Campinas (UNICAMP), Campinas, SP, Brazil.
}

*Corresponding author: alvinbn@gmail.com

doi: $10.15414 / j m b f s .2016 .6 .1 .636-640$

\section{ARTICLE INFO}

Received 6. 7. 2015

Revised 2. 3. 2016

Accepted 3. 3. 2016

Published 1. 8. 2016

Regular article

OPEN $\partial_{\text {AcCESS }}$

\section{ABSTRACT}

The aim of this work was to evaluate the synergistic effect of combined treatment with high hydrostatic pressure (HHP) and an aqueous extract of Punica granatum (pomegranate) peels on the survival of Shiga toxin-producing Escherichia coli (STEC). Our results showed that HHP $\left(250 \mathrm{MPa}, 60 \mathrm{~min}, 25^{\circ} \mathrm{C}\right)$ reduced the STEC bacterial load in milk and tryptic soy broth culture medium by about 2.5 and 3.5 logs, respectively. Under these conditions, HHP did not alter the cytotoxicity of Shiga toxins in Vero and human umbilical vein endothelial cells. Treatment with up to $30 \mathrm{mg}$ of pomegranate extract/mL caused negligible inactivation, but a combination of HHP and pomegranate extract $(3 \mathrm{mg} / \mathrm{mL})$ produced bacterial inactivation from $10^{9} \mathrm{CFU} / \mathrm{mL}$ to undetectable levels of viable bacteria. These findings suggest that a combination of HHP and pomegranate extract may be potentially effective in bacterial inactivation during food processing, particularly in the elimination of important foodborne pathogens such as STEC. a

Keywords: Escherichia coli, High Hydrostatic Pressure, Pomegranate extract, Shiga toxins, STEC

\section{INTRODUCTION}

Shiga toxin-producing Escherichia coli (STEC) are important food and waterborne bacterial pathogens. These microorganisms produce potent cytotoxins, called Shiga toxins (Stx) that, for more than three decades, have been linked to large outbreaks of gastrointestinal illness (Manning et al., 2008). STEC strains, particularly E. coli $\mathrm{O} 157: \mathrm{H} 7$, cause a wide range of illnesses such as bloody diarrhea, hemorrhagic colitis, hemolytic uremic syndrome (HUS) and, in some cases, death (Kaper et al., 2004).

Many cases of foodborne diseases worldwide are associated with the consumption of STEC-contaminated ground beef, water, raw milk, unpasteurized fruit juices, vegetables and other fresh produce (Yoon and Hovde, 2008; FDA, 2012). Contamination with as few as ten STEC O157:H7 strain bacteria is sufficient to cause human infection (FDA, 2009). Recent studies estimate that in the United States of America the mean annual cost of treating foodborne illnesses caused by STEC O157:H7 strains is US\$ 635 million (Scharff, 2012)

Cattle are the major reservoir for STEC and undercooked ground beef is one of the most common causes of STEC O157:H7 strain infections (Riley et al., 1983; Rangel et al., 2005). The consumption of contaminated raw milk dairy products may also be an important route of STEC infection (Miszczycha et al., 2014) Contamination rates of up to 10\% have been reported for STEC O157:H7 in bulk tank milk samples collected in North America (D'Amico et al., 2010).

Pasteurization is the recommended procedure for controlling the microbiological risks associated with the consumption of raw milk since it substantially decreases or eliminates pathogens and effectively prevents disease transmission (Guh et al., 2010). However, high temperatures may cause detrimental changes to processed foods, leading to undesirable changes that can affect the nutritional and organoleptic characteristics, resulting in products that are nutritionally different when compared to similar fresh products (San Martín et al., 2002).

Non-thermal techniques, including high hydrostatic pressure (HHP), have received considerable interest from the food industry, with pressures of 100-1200 MPa being particularly effective in the inactivation of a wide variety of microorganisms, including foodborne pathogens. Another important attribute of HHP is that this technique also improves rennet or acid coagulation of milk with no detrimental effect on nutritional quality, flavor and texture (Chawla et al., 2011).
HHP is a powerful tool for developing novel dairy products of better nutritional and sensory quality, novel texture and increased shelf-life. Non-thermal processing may improve the energy efficiency of food processing. For these reasons, high pressure technology is increasingly being used to produce valueadded food products. HHP can be used to process liquid and solid (watercontaining) foods, with the advantages that it kills bacteria in raw food, extends the shelf-life and enhances desired attributes, e.g., digestibility (Makhal $\boldsymbol{e t}$ al., 2003).

Appropriate combinations of pressure and temperature may be a useful alternative to achieve a suitable synergistic effect in reducing the bacterial load in foods (Moussa $\boldsymbol{e t}$ al., 2006). The antibacterial activity of aqueous and ethanolic extracts of Punica granatum (pomegranate) peels against different pathogens, such as Pseudomonas aeruginosa and Staphylococcus aureus, has been described (Reddy et al., 2007). The exceptional antioxidant potential and promising medicinal properties of pomegranate peels have led to intensive research of its role in human health (Lansky and Newman, 2007). An extract of pomegranate peels has been shown to inhibit the growth of STEC O157:H7 strain (Howell and D'Souza, 2013) and also exhibited antidiarrheal properties. The presence of water-soluble polyphenols in the aqueous extract of pomegranate peels may mediate its antidiarrheal activity (Qnais et al., 2007).

Based on the foregoing studies, the objective of this work was to evaluate the effect of HHP (250 MPa for 10, 20, 30, 45 and $60 \mathrm{~min}$ at $25^{\circ} \mathrm{C}$ ) combined with different concentrations of an aqueous extract of pomegranate on the survival of STEC O157:H7 inoculated into different substrates (milk and culture medium) The effect of HHP $\left(250 \mathrm{MPa}, 60 \mathrm{~min}, 25^{\circ} \mathrm{C}\right)$ on the biological activity of the Shiga toxins (Stx1 and Stx2) produced by STEC O157:H7 strain was also evaluated. Understanding the behavior of STEC strains under different synergistic conditions may be useful for developing more effective methods of inactivating foodborne pathogens.

\section{MATERIAL AND METHODS}

\section{Strains}

The following E. coli strains were used for the different assays: O157:H7 EDL933 (produces Stx1 and Stx2), C600 K-12 (does not produce Stx1 and Stx2), 
C600 H19B (produces only Stx1) and C600 933W (produces only Stx2). All of the strains were from the bacterial collection of the Laboratory of Virulence Factors of the Institute of Biology at UNICAMP (Campinas, SP, Brazil).

\section{HHP system}

HHP was generated by a pump operated by an engine that injected ethanol via a pipeline (HIP model 37-5.75-60; Erie, PA, USA) into a metal chamber (external dimensions, $91.3 \mathrm{~mm}$ wide x $91.3 \mathrm{~mm}$ deep; internal volume capacity, $24.5 \mathrm{~mL}$; nominal high pressure capacity up to $400 \mathrm{MPa}$; ISS HP Cell, ISS Inc. Champaign, IL, USA) (Bispo et al., 2007). The time required to increase the pressure from atmospheric pressure to $250 \mathrm{MPa}$ was $2.5 \mathrm{~min}$ and the decompression time was $1.0 \mathrm{~min}$. The pressure chamber was connected to a circulating water bath fitted with a temperature controller (Marconi, Piracicaba, SP, Brazil). For HHP treatment, the different samples were placed in polyethylene bags, sealed at high temperature and placed in the high pressure chamber (Souza et al., 2013).

\section{Preparation of milk contaminated with $E$. coli $0157: H 7$ strain}

Contaminated milk was prepared as described by Durães-Carvalho et al. (2012), with slight modifications. E. coli O157:H7 EDL933 strain was cultured in tryptic soy broth (TSB) and incubated at $37{ }^{\circ} \mathrm{C}$ overnight. The number of bacteria was adjusted to $\sim 10^{9} \mathrm{CFU} / \mathrm{mL}$ using the McFarland nephelometric scale. The bacterial suspension was centrifuged at $10,000 \times g$ and the supernatant was discarded. The bacterial pellet was washed three times with sterile PBS, pH 7.2, and resuspended in filter-sterilized whole milk for immediate use in the HHP assays.

\section{Preparation of aqueous pomegranate extract}

Pomegranate fruits were washed with distilled water and air-dried. Pomegranate peel was removed and $40 \mathrm{~g}$ was placed in an Erlenmeyer flask. After adding 100 $\mathrm{mL}$ of distilled water, the mixture was stored in the dark at $25{ }^{\circ} \mathrm{C}$ for $24 \mathrm{~h}$ and sterilized by filtration using $0.22 \mu \mathrm{m}$ pore-sized filters (Millipore, São Paulo, SP, Brazil). The extract was lyophilized and resuspended in sterile distilled water, filter-sterilized and stored at $-20{ }^{\circ} \mathrm{C}$ until use. The pomegranate species was identified at the Department of Plant Biology, Institute of Biology at UNICAMP), Brazil, and a voucher specimen (code UEC037017) was deposited in the Herbarium of this Department.

\section{HHP assays}

\section{Inactivation of E. coli O157:H7 strain by HHP}

E. coli $\mathrm{O} 157: \mathrm{H} 7$ EDL933 was cultured in TSB and incubated overnight at $37^{\circ} \mathrm{C}$ with shaking. The bacterial cultures were adjusted to a cell concentration of $\sim 10^{\circ}$ $\mathrm{CFU} / \mathrm{mL}$ using the McFarland nephelometric scale. The bacterial suspension and samples of whole milk contaminated with E. coli O157:H7 EDL933 were used for the pressure treatment assays. A pressure of $250 \mathrm{MPa}$ was applied to each sample at $25{ }^{\circ} \mathrm{C}$ for various times $(10,20,30,45$ and $60 \mathrm{~min})$ after which the bacterial viability was analyzed by plating 10 -fold serial dilutions of bacterial suspensions, prepared in sterile PBS, pH 7.2, on MacConkey agar plates. The plates were incubated at $37^{\circ} \mathrm{C}$ for $24 \mathrm{~h}$ before counting the colonies. This assay was done in triplicate.

\section{Effect of HHP combined with pomegranate extract}

This assay was done under three sets of conditions. Initially, we examined the effect of high pressure $\left(250 \mathrm{MPa}, 60 \mathrm{~min}, 25^{\circ} \mathrm{C}\right)$ on bacterial suspensions in TSB and milk contaminated with E. coli O157:H7 EDL933. Next, the antimicrobial effect of a pomegranate aqueous extract was tested. For this, bacterial suspensions in TSB or contaminated whole milk were treated with the pomegranate aqueous extract $(3 \mathrm{mg} / \mathrm{mL}$ and $30 \mathrm{mg} / \mathrm{mL})$ after which the samples were left at room temperature for $1 \mathrm{~h}$. Finally, the effect of HHP combined with pomegranate extract was examined using the same pressure and time parameters as for the previous two steps. For all three steps, viable bacteria were quantified after incubation at $37^{\circ} \mathrm{C}$ for $24 \mathrm{~h}$ in MacConkey agar plates.

\section{In vitro cytotoxicity assays}

\section{Preparation of cell-free filtrates}

E. coli O157:H7 EDL933, C600 H19B, C600 933W and C600 K-12 strains were cultured in TSB and incubated overnight at $37{ }^{\circ} \mathrm{C}$ with shaking. The bacterial cultures were centrifuged at $10,000 \times g$ for $10 \mathrm{~min}$ and the supernatant was sterilized by filtration using $0.22 \mu \mathrm{m}$ pore-sized membranes before doing the experiments.

\section{MTT reduction assay}

The cytotoxicity of the different cell-free filtrates was assessed using the MTT (3-[4,5-dimethylthiazole]-2,5-diphenyltetrazolium bromide thiazole blue) cytotoxicity assay in African green monkey kidney cells (Vero) and human umbilical vein endothelial (HUVEC) cells, according to Bernedo-Navarro et al. (2014). One hundred microliters of cell-free filtrate was added to cell-containing wells and the microplates were incubated at $37{ }^{\circ} \mathrm{C}$ for $45 \mathrm{~h}$ in a $5 \% \mathrm{CO}_{2}$ atmosphere. After this step, the culture medium of each well was discarded and $100 \mu \mathrm{L}$ of MTT ( $2 \mathrm{mg} / \mathrm{mL}$ in PBS) was added to each well, after which the plate was incubated for $3 \mathrm{~h}$ at the same temperature in a $5 \% \mathrm{CO}_{2}$ atmosphere. Finally, the MTT solution was discarded and $100 \mu \mathrm{L}$ of isopropanol-hydrochloric acid (1 N) $(24: 1, v / v)$ was added to each well. The resulting absorbance was read at 450 $\mathrm{nm}$ using an ELISA microplate reader (Epoch, BioTek Instruments Inc., VT, USA) and the percentage of viable cells was calculated. This assay was done in triplicate.

\section{Effect of HHP on the cytotoxicity of shiga toxins}

To assess whether HHP affected the cytotoxicity of Shiga toxins (Stx), bacterial cultures of E. coli O157:H7 (Stx1+ and Stx2+), E. coli C600 H19B (Stx1+), E. coli $\mathrm{C} 600(\mathrm{Stx} 2+)$ and E. coli $\mathrm{C} 600 \mathrm{~K}-12$ (non-producer of Stx) strains were cultured in TSB at $37{ }^{\circ} \mathrm{C}$ overnight. After incubation, $1 \mathrm{~mL}$ of each bacterial culture was pressurized at $250 \mathrm{MPa}$ for $1 \mathrm{~h}$ at $25{ }^{\circ} \mathrm{C}$ followed by centrifugation $\left(10,000 \times g, 10 \mathrm{~min}, 4^{\circ} \mathrm{C}\right)$. The bacterial supernatant was filter-sterilized and 100 $\mu \mathrm{L}$ of two-fold dilutions of this free-cell filtrate (in DMEM) were assayed for cytotoxicity on Vero and HUVEC cells. Cytotoxicity was monitored using an inverted microscope (Nikon Instruments, Tokyo, Japan) after incubation for $24 \mathrm{~h}$ at $37{ }^{\circ} \mathrm{C}$ in a $5 \% \mathrm{CO}_{2}$ atmosphere. The results were expressed as the highest dilution at which cytotoxicity was observed (cytotoxicity titer). This assay was done in triplicate.

\section{Statistical analysis}

The results were expressed as the mean \pm SD (standard deviation). Statistical comparisons were done using GraphPad Prism v.5.01 (GraphPad Software, San Diego, CA, USA; http://www.graphpad.com).

\section{RESULTS}

\section{HHP and the viability of $E$. coli in TSB medium and milk}

The Fig 1 shows the effect of HHP on the inactivation of E. coli O157:H7 EDL933 strain in TSB and milk. Bacterial inactivation was assessed after exposure to high pressure (250 MPa) for different times. The inactivation in TSB (from $10^{9}$ to $10^{5.5} \log \mathrm{CFU} / \mathrm{mL}$, approximately) was slightly higher than that in contaminated milk (from $10^{8.5}$ to $10^{6.0} \log \mathrm{CFU} / \mathrm{mL}$ ).

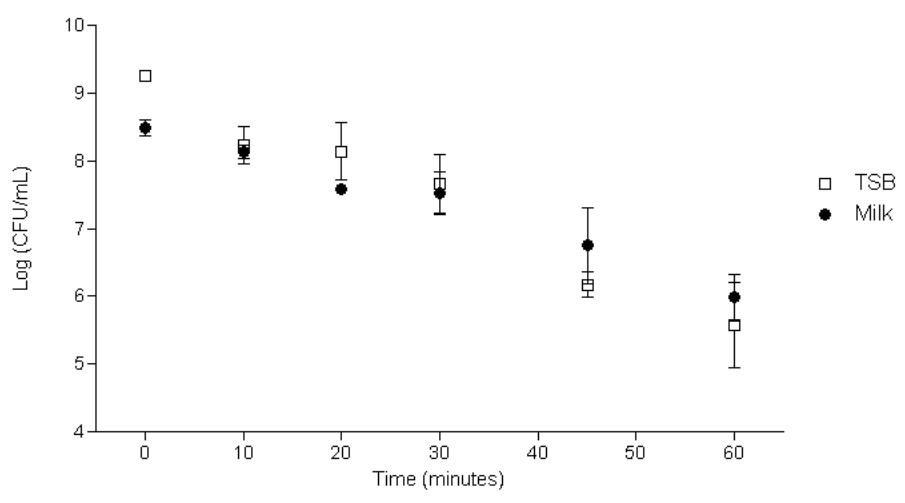

Figure 1 Kinetics for the inactivation of E. coli O157:H7 EDL933 by HHP (250 $\mathrm{MPa}$ ) in TSB medium and milk. The points represent the mean $\pm \mathrm{SD}$.

Effect of HHP combined with pomegranate aqueous extract on the viability of $E$. coli $\mathrm{O157}: \mathrm{H7}$

\section{EDL933 strain in TSB and whole milk}

The Fig 2 shows that treatment of the bacterial culture in TSB medium and milk at $250 \mathrm{MPa}$ for $1 \mathrm{~h}$ reduced the bacterial load by 4.0 and 2.5 orders of magnitude, respectively, in agreement with the results in Fig 1. The combination of HHP with pomegranate aqueous extract in TSB and milk contaminated with this pathogen resulted in total inactivation of the bacterial load (from $10^{9}$ to 0 $\mathrm{CFU} / \mathrm{mL}$ ) (Fig 2). 


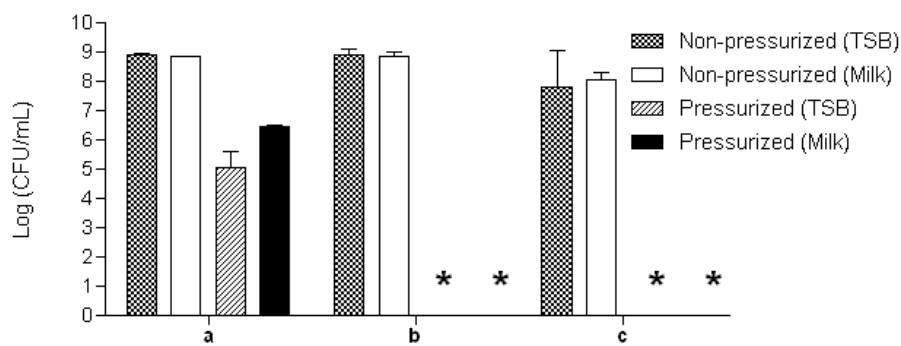

Figure 2 Effect of a combination of HHP (250 MPa, $60 \mathrm{~min}$ ) and pomegranate aqueous extract on E. coli O157:H7 EDL933 inactivation in TSB culture medium and milk. a: No extract; b: $3 \mathrm{mg}$ of extract $/ \mathrm{mL}$; : $30 \mathrm{mg}$ of extract $/ \mathrm{mL}$. * No viable bacteria detected. The columns represent the mean $\pm \mathrm{SD}$.

\section{Cytotoxicity of pomegranate aqueous extract in VERO and HUVEC cells}

At concentrations of $3 \mathrm{mg} / \mathrm{mL}$ and $30 \mathrm{mg} / \mathrm{mL}$ the pomegranate aqueous extract was cytotoxic to Vero cells and reduced the cell viability by $\sim 50 \%$ (Fig $3 \mathrm{~A}$ ), but was not cytotoxic to HUVEC cells (Fig 3B).

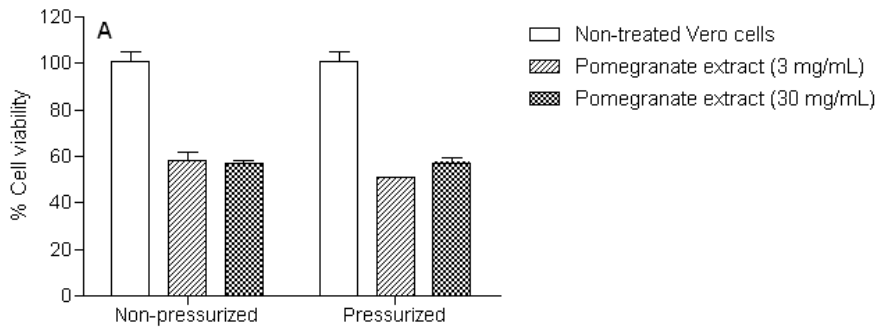

Figure 3 Cytotoxicity of pomegranate aqueous extract in Vero (A) and HUVEC cells (B). The columns represent the mean \pm SD.

\section{Cytotoxicity assessed by the MTT assay}

\section{Cytotoxicity of E. coli O157:H7 EDL933 strain cell-free filtrates in VERO and HUVEC cells}

The cytotoxicity of $E$. coli cultured in TSB medium and subjected to $250 \mathrm{MPa}$ for $1 \mathrm{~h}$ was similar in Vero and HUVEC cells (Fig 4). There were no significant differences in cell viability among the different conditions tested (cell-free filtrate, pressurized O157:H7 bacterial culture). HHP did not affect the biological activity of the toxin (Table 1)
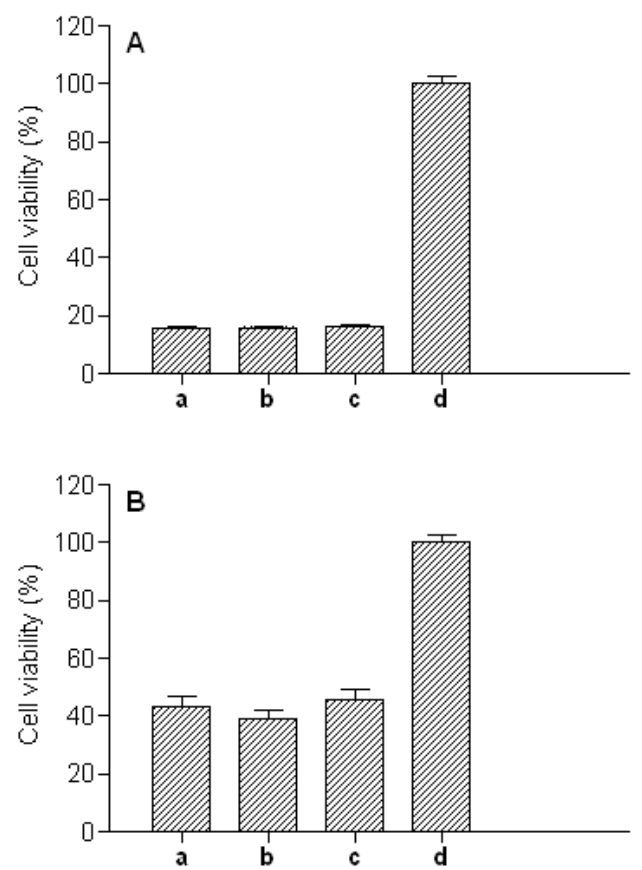

Figure 4 Cytotoxicity of $E$. coli $\mathrm{O} 157: \mathrm{H} 7$ EDL933 cell-free filtrates in Vero (A) and HUVEC cells (B) as assessed by the MTT assay. a: STEC O157:H7 EDL933 cell-free filtrate, b: Pressurized STEC O157:H7 EDL933 cell-free filtrate, c: Pressurized STEC O157:H7 EDL933 culture, d: Non-treated cells. The columns represent the mean $\pm \mathrm{SD}$.
Effect of HHP on the cytotoxicity of shiga toxins from different $E$. coli strains

Table 1 shows the effect of HHP on the cytotoxicity of different $E$. coli strains Exposure of cell-free filtrates of E. coli O157:H7 EDL933, E. coli C600 H19B and E. coli $\mathrm{C} 600933 \mathrm{~W}$ strains at $250 \mathrm{MPa}$ for $1 \mathrm{~h}$ did not affect the biological activity of Stx1 and Stx2 when compared with non-pressurized samples.

Table 1 Effect of HHP treatment on the cytotoxicity of cell-free filtrates of $E$. coli strains.

\begin{tabular}{lcccc}
\hline \multirow{2}{*}{ E. coli strains } & \multicolumn{2}{c}{ Genotype } & Treatment & $\begin{array}{c}\text { Cytotoxicity titer in } \\
\text { Vero cells }\end{array}$ \\
\cline { 2 - 3 } C600 K12 & stx1 & stx2 & & $\mathrm{P}^{*}$ \\
& - & - & $\mathrm{NP}$ & 0 \\
O157:H7 EDL933 & + & + & $\mathrm{P}^{*}$ & $1 / 1024$ \\
& & & $\mathrm{NP}$ & $1 / 1024$ \\
C600 H19B & + & - & $\mathrm{P} *$ & $1 / 256$ \\
& & & $\mathrm{NP}$ & $1 / 256$ \\
C600 933W & - & + & $\mathrm{P} *$ & $1 / 256$ \\
& & & $\mathrm{NP}$ & $1 / 256$ \\
\hline
\end{tabular}

*P $=$ pressurized $\left(250 \mathrm{MPa}, 60 \mathrm{~min}, 25^{\circ} \mathrm{C}\right) ; \mathrm{NP}=$ non-pressurized

\section{DISCUSSION}

The use of HHP is a promising approach for the inactivation of microorganisms in milk and derived products. Despite a low initial bacterial load of STEC O157:H7 in milk, this pathogen can grow during cheese processing to reach levels high enough to be considered a threat to human health (Montet $\boldsymbol{e t}$ al., 2009). In this context, the use of methods capable of bacterial inactivation may represent an alternative for controlling the levels of STEC strains in milk destined for the manufacturing of products for human consumption (Farrokh et al., 2013).

Another promising alternative for reducing bacterial load is the use of pomegranate extract, as has been applied to several bacterial species (AI Laham and Al Fader, 2013). Specific compounds obtained from pomegranate extract, such as punicalagin, when used in combination with classic antimicrobials, can potentiate their effects and significantly reduce the toxic side effects (Endo et al. 2010). Rodriguez et al. (2005) found that pressurization of cheese (300 MPa, 10 min, $10^{\circ} \mathrm{C}$ ) reduced the bacterial load of STEC O157:H7 to undetectable levels when combined with the application of several bacteriocins. De Lamo-Castellvi et al. (2006) also reported that HHP (400-500 MPa) reduced the bacterial load of STEC 0157:H7 in cheese curd.

In the present study, the kinetics of $E$. coli O157:H7 EDL933 inactivation by HHP was examined (Fig 1). The pressure-induced inactivation of STEC O157:H7 EDL933 in TSB culture medium and milk was similar, with a reduction in the bacterial load of $\sim 3$ orders of magnitude (from $10^{9}$ to $10^{6} \mathrm{CFU} / \mathrm{mL}$ ). Similar results were observed using $250 \mathrm{MPa}$ for the inactivation of $A$. hydrophila AH 191 strain in whole milk (Durães-Carvalho et al., 2012). To improve the HHP-mediated inactivation of E. coli, the treatment was combined with aqueous pomegranate extract $(3 \mathrm{mg} / \mathrm{mL}$ and $30 \mathrm{mg} / \mathrm{mL})$ that is well known to have antimicrobial properties. Total bacterial inactivation was observed with this combination ( $>10^{9}$ fold reduction) when compared to the extract alone (Fig 2), indicating synergism between HHP and the extract. The TBS or milk in which the bacteria were grown apparently did not influence the inactivation by HHP and extract (Fig 2).

To analyze the cytotoxicity of the pomegranate extract, Vero and HUVEC cells were treated with the aqueous extract ( 3 and $30 \mathrm{mg} / \mathrm{mL}$ ). We observed $\sim 50 \%$ cell mortality in Vero cells (Fig 3A), while in HUVEC cells no significant cytotoxic effects were observed (Fig 3B). HHP-treated extract and untreated extract showed similar cytotoxicity at both concentrations (Fig 3A,B). According to Endo et al. (2010), Vero cells were sensitive to punicalagin, a compound present in large quantities in pomegranate, after application of the extract at a concentration of $60 \mathrm{mg} / \mathrm{mL}$.

Stx-mediated endothelial cell damage may result in bleeding characteristic of hemorrhagic colitis associated with some STEC infections, thereby allowing the toxin to reach the bloodstream and damage endothelial cells at distant sites such as the kidney and brain (Jacewicz et al., 1999). However, at the two concentrations tested, the extract had little effect on the viability of HUVEC cells (Fig 3B). This finding suggests that pomegranate extract does not contribute to endothelial cell damage and would not enhance the cytotoxicity of Stx toxins in these cells.

We also examined the effect of HHP on Stx virulence since high pressure inactivates a variety of bacteria and viruses. HHP had little or no effect on the cytotoxicity of these toxins in Vero and HUVEC cells (Fig 4A and Fig 4B, respectively), specifically Shiga toxins 1 and 2 (Stx1 and Stx2) (Table 1). This finding agreed with previous reports showing a lack of bacterial toxin inactivation by HHP (Guimarães et al., 2002; Durães-Carvalho et al., 2012).

A relevant concern related to the use of HHP for bacterial inactivation is the resistance of some microorganisms to this treatment. Indeed, the development of 
resistance to high pressure has important implications for the use of pressure technology in the inactivation of nonpathogenic and pathogenic E. coli strains in food preservation methods (Hauben et al., 1997). Vanlint et al. (2012) described the isolation of extremely HHP-resistant mutants of E. coli MG1655 strain (resistant up to $2 \mathrm{GPa}$ ) by applying a selective enrichment approach based on consecutive cycles of increasingly severe HHP shocks. These authors subsequently showed that the capacity to develop extreme resistance to HHP was mainly related to species of $E$. coli, although not all isolates shared this characteristic (Vanlint et al., 2012). According to these authors, once acquired, HHP resistance was apparently a stable trait and showed that E. coli strains readily survive to $800 \mathrm{MPa}$.

According to Hauben et al. (1997), if barotolerant strains can grow under commercial pressurization processes then they represent a serious threat to the safety and stability of pressure-processed foods. For these reasons, we believe that the combination of $\mathrm{HHP}$ at relatively moderate hydrostatic pressure $(250$ $\mathrm{MPa}$ ) and aqueous pomegranate extract could be a promising alternative for avoiding the selection of pressure-tolerant pathogenic strains and for inactivating important foodborne pathogens such as STEC O157:H7 strain.

\section{CONCLUSIONS}

Our results showed that bacterial inactivation was drastically increased when HHP treatment $\left(250 \mathrm{MPa}\right.$ at $25^{\circ} \mathrm{C}$ during 60 minutes) was applied together with pomegranate peels extract, leading to total inactivation of STEC O157:H7 in contaminated milk. Considering the promising future of HHP technique in food industry and that no viable bacteria were detected after the application of combined treatment, we consider that this process has potential for reduction of bacterial load in food contaminated by STEC O157:H7. The synergistic effect of moderate pressure and natural extract of pomegranate on bacterial inactivation, make it economically attractive for industry and may prevent the selection of barotolerant pathogenic strains. Additional studies will be needed to improve the efficiency of this treatment and to achieve the neutralization of biological activity of the toxins produced by this important pathogen.

Acknowledgments: The authors thank Ana Stella Menegon Degrossoli, Juliana Mattoso, Rogério Arcuri Conceição and Luiz Henrique Soares Tibo for technical support. This work was supported by Fundação de Amparo à Pesquisa do Estado de São Paulo (FAPESP) and Coordenação de Aperfeiçoamento de Pessoal de Nível Superior (CAPES), Brazil.

\section{REFERENCES}

AL LAHAM, S.A., Al Fadel, F.M. 2013. The Anti-Bacterial Effect of Punica granatum Extracts Against Antibiotic Resistant Pasteurella haemolytica. Jundishapur Journal of Microbiology, 6(9).http://dx.doi.org/10.5812/jim.7750

BERNEDO-NAVARRO, R. A., MIYACHIRO, M. M., DA SILVA, M. J., REIS C. F., CONCEIÇÃO, R. A., GATTI, M. S. V., YANO, T. 2014. Peptides derived from phage display libraries as potential neutralizers of Shiga toxin-induced cytotoxicity in vitro and in vivo. Journal of Applied Microbiology, 116 (5), 1322-1333.http://dx.doi.org/10.1111/jam.12451

BISPO, J.A.C., SANTOS, J.L.R., LANDINI, G.F., GONCALVES, J.M., BONAFE, C.F.S. 2007. pH dependence of the dissociation of multimeric hemoglobin probed by high hydrostatic pressure. Biophysical Chemistry, 125 (23) 341-349.http://dx.doi.org/10.1016/j.bpc.2006.09.009

CHAWLA, R., PATIL, G.R., SINGH, A.K. 2011. High hydrostatic pressure technology in dairy processing: a review. Journal of Food Science Technology, 48 (3), 260-268.http://dx.doi.org/10.1007/s13197-010-0180-4

D'AMICO, D.J., DRUART, M.J., DONNELLY, C.W. 2010. Behavior of Escherichia coli O157:H7 during the manufacture and aging of Gouda and stirred-curd Cheddar cheeses manufactured from raw milk. Journal of Food Protection, 73, 2217-2224.

DE LAMO-CASTELLVÍ, S., CAPELLAS, M., ROIG-SAGUÉS, A.X., LÓPEZPEDEMONTE, T., HERNÁNDEZ-HERRERO, M.M., GUAMIS, B. 2006. Fate of Escherichia coli strains inoculated in model cheese elaborated with or without starter and treated by high hydrostatic pressure. Journal of Food Protection, 69, 2856-2864.

DURÃES-CARVALHO, R., SOUZA, A.R., MARTINS, L.M., SPROGIS, A.C.S., BISPO, J.A.C., BONAFE, C.F.S., YANO, T. 2012. Effect of high hydrostatic pressure on Aeromonas hydrophila AH 191 growth in milk. Journa of Food Science, 77(8), M417-424.http://dx.doi.org/10.1111/j.17503841.2012.02819.x

ENDO, E.H., CORTEZ, D.A.G., UEDA-NAKAMURA, T., NAKAMURA, C.V., DIAS FILHO, B.P. 2010. Potent antifungal activity of extracts and pure compound isolated from pomegranate peels and synergism with fluconazole against Candida albicans. Research Microbiology, 161(7), 534 540.http://dx.doi.org/10.1016/j.resmic.2010.05.002

FARROKH, C., JORDAN, K., AUVRAY, F., GLASS, K., OPPEGAARD, H., RAYNAUD, S., THEVENOT, D., CONDRON, R., DE REU, K., GOVARIS, A., HEGGUM, K., HEYNDRICKX, M., HUMMERJOHANN, J., LINDSAY, D., MISZCZYCHA, S., MOUSSIEGT, S., VERSTRAETE, K., CERF, O. 2013.
Review of Shiga-toxin-producing Escherichia coli (STEC) and their significance in dairy production. International Journal of Food Microbiology, 162(2), 190212.http://dx.doi.org/10.1016/j.ijfoodmicro.2012.08.008

Food and Drug Administration (FDA). 2009. Annex 3 Public Health Reasons/Administrative Guidelines. Chapter 2 - Management and Personnel. Available

http://www.fda.gov/Food/GuidanceRegulation/RetailFoodProtection/FoodCode/ cm189171.htm Accessed March 26, 2015

Food and Drug Administration (FDA). 2012. Bad bug book: Foodborne pathogenic microorganisms and natural toxins handbook, 2nd ed. US Food and Drug Administration, Silver Spring, 74-78. Available at: http://www.fda.gov/Food/FoodborneIllnessContaminants/CausesOfIllnessBadBu gBook/ucm2006773.htm. Accessed March 26, 2015.

GUH, A., PHAN, Q., NELSON, R., PURVIANCE, K., MILARDO, E. KINNEY, S., MSHAR, P., KASACEK, W., CARTTER, M. 2010. Outbreak of Escherichia coli O157 associated with raw milk, Connecticut, 2008. Clinical Infectious Diseases, 51(12), 1411-1417.http://dx.doi.org/10. 1086/657304

GUIMARÃES, M.S., ANDRADE, J.R.C., FREITAS-ALMEIDA, A.C., FERREIRA, M.C.S. 2002. Aeromonas hydrophila vacuolating activity in the Caco-2 human enterocyte cell line as a putative virulence factor. (Federation of European Microbiological Societies) Microbiology Letters, 207(2), 127131.http://dx.doi.org/10.1016/S0378-1097(01)00527-4

HAUBEN, K.J., BARTLETT, D.H., SOONTJENS, C.C., CORNELIS, K., WUYTACK, E.Y., MICHIELS, C.W. 1997. Escherichia coli mutants resistant to inactivation by high hydrostatic pressure. Applied and Environmental Microbiology, 63, 945-950.

HAYASHI, R.1991. High pressure in food processing and preservation: Principle, application and development. High Pressure Research, 7(1-6), 1521.http://dx.doi.org/10.1080/08957959108245497

HOWELL, A.B., D’SOUZA, D.H. 2013. The Pomegranate: Effects on Bacteria and Viruses That Influence Human Health. Evidence-Based Complementary and Alternative Medicine 2013, e606212.http://dx.doi.org/10.1155/2013/606212

JACEWICZ, M.S., ACHESON, D.W., BINION, D.G., WEST, G.A., LINCICOME, L.L., FIOCCHI, C., KEUSCH, G.T. 1999. Responses of human intestinal microvascular endothelial cells to Shiga toxins 1 and 2 and pathogenesis of hemorrhagic colitis. Infection and Immunity, 67, 1439 1444.http://dx.doi.org/10.1155/2013/606212

KAPER, J.B., NATARO, J.P., MOBLEY, H.L. 2004. Pathogenic Escherichia $\begin{array}{llll}\text { coli. Nature Reviews } & \text { Microbiolology, }\end{array}$ 140.http://dx.doi.org/10.1038/nrmicro818

LANSKY, E.P., NEWMAN, R.A. 2007. Punica granatum (pomegranate) and its potential for prevention and treatment of inflammation and cancer. Journal of Ethnopharmacology, $109(2)$,

206.http://dx.doi.org/10.1016/i.jep.2006.09.006

MAKHAL, S., VASHISHTHA, B., KANAWJIA, S.K. 2003. High hydrostatic pressure in food preservation: Philosophy and development. Indian Food Industry, 22(1): 38-45

MANNING, S.D., MOTIWALA, A.S., SPRINGMAN, A.C., QI, W., LACHER, D.W., OUELLETTE, L.M., MLADONICKY, J.M., SOMSEL, P., RUDRIK, J.T., DIETRICH, S.E., ZHANG, W., SWAMINATHAN, B., ALLAND, D., WHITTAM, T.S. 2008. Variation in virulence among clades of Escherichia coli O157:H7 associated with disease outbreaks. Proceedings of the National Academy of Sciences of the United States of America, 105(12), 48684873.http://dx.doi.org/10.1073/pnas.0710834105

MISZCZYCHA, S.D., THÉVENOT, J., DENIS, S., CALLON, C., LIVRELLI, V., ALRIC, M., MONTEL, M.-C., BLANQUET-DIOT, S., THEVENOTSERGENTET, D. 2014. Survival of Escherichia coli O26:H11 exceeds that of Escherichia coli $0157: \mathrm{H} 7$ as assessed by simulated human digestion of contaminated raw milk cheeses. International Journal of Food Microbiology, 172, 40-48.http://dx.doi.org/10.1016/i.ijfoodmicro.2013.11.029

MONTET, M.P., JAMET, E., GANET, S., DIZIN, M., MISZCZYCHA, S., DUNIĖRE, L., THEVENOT, D., VERNOZY-ROZAND, C. 2009. Growth and Survival of Acid-Resistant and Non-Acid-Resistant Shiga-ToxinProducing Escherichia coli Strains during the Manufacture and Ripening of Camembert Cheese. International Journal of Microbiology, 2009.http://dx.doi.org/10.1155/2009/653481

MOUSSA, M., PERRIER-CORNET, J.-M., GERVAIS, P. 2006. Synergistic and antagonistic effects of combined subzero temperature and high pressure on inactivation of Escherichia coli. Applied and Environmental Microbiology, 72(1), 150-156.http://dx.doi.org/10.1128/AEM.72.1.150-156.2006

QNAIS, E.Y., ELOKDA, A.S., ABU GHALYUN, Y.Y., ABDULLA, F.A. 2007. Antidiarrheal Activity of the Aqueous Extract of Punica granatum (Pomegranate) Peels. Pharmaceutical Biology, 45(9), 715 720.http://dx.doi.org/10.1080/13880200701575304

RANGEL, J.M., SPARLING, P.H., CROWE, C., GRIFFIN, P.M., SWERDLOW, D.L. 2005. Epidemiology of Escherichia coli O157:H7 Outbreaks, United States, 1982-2002. Emerging Infectious Diseases, 11(4), 603 609.http://dx.doi.org/10.3201/eid1104.040739

REDDY, M.K., GUPTA, S.K., JACOB, M.R., KHAN, S.I., FERREIRA, D 2007. Antioxidant, antimalarial and antimicrobial activities of tannin-rich 
fractions, ellagitannins and phenolic acids from Punica granatum L. Planta

Medica, 73(5), 461-467.http://dx.doi.org/10.1055/s-2007-967167

RILEY, L.W., REMIS, R.S., HELGERSON, S.D., MCGEE, H.B., WELLS, J.G.,

DAVIS, B.R., HEBERT, R.J., OLCOTT, E.S., JOHNSON, L.M., HARGRETT,

N.T., BLAKE, P.A., COHEN, M.L. 1983. Hemorrhagic colitis associated with a rare Escherichia coli serotype. The New England Journal of Medicine, 308(4), 681-685.http://dx.doi.org/10.1097/00006454-198307000-00031

RODRIGUEZ, E., ARQUES, J.L., NUÑEZ, M., GAYA, P., MEDINA, M. 2005

Combined effect of high-pressure treatments and bacteriocin-producing lactic acid bacteria on inactivation of Escherichia coli O157:H7 in raw-milk cheese Applied and Environmental Microbiology, 71(7), 33993404.http://dx.doi.org/10.1128/AEM.71.7.3399-3404.2005

SAN MARTÍN, M.F., BARBOSA-CÁNOVAS, G.V., SWANSON, B.G. 2002.

Food processing by high hydrostatic pressure. Critical Reviews in Food Science and Nutrition, 42(6), 627-645.http://dx.doi.org/10.1080/20024091054274

SCHARFF, R.L. 2012. Economic burden from health losses due to foodborne illness in the United States. Journal of Food Protection, 75, 123 131.http://dx.doi.org/10.4315/0362-028X.JFP-11-058

SOUZA, A.R. DE, DEMONTE, A.L.S.S.M. DA C., COSTA, K. DE A., FARIA, M.A.C., DURÃES-CARVALHO, R., LANCELLOTTI, M., BONAFE, C.F.S., 2013. Potentiation of high hydrostatic pressure inactivation of Mycobacterium by combination with physical and chemical conditions. Applied Microbiology and Biotechnology, 97(16), 7417-7425.http://dx.doi.org/10.1007/s00253-013-5067-7 VANLINT, D., RUTTEN, N., MICHIELS, C.W., AERTSEN, A. 2012. Emergence and stability of high-pressure resistance in different food-borne pathogens. Applied Environmental and Microbiology, 78(9), 3234 3241.http://dx.doi.org/10.1128/AEM.00030-12

YOON, J.W., HOVDE, C.J. 2008. All blood, no stool: enterohemorrhagic Escherichia coli O157:H7 infection. Journal Veterinary Science, 9(3), 219 231.http://dx.doi.org/10.4142/jvs.2008.9.3.219 